\title{
Intraspecific habitat adaptation: How the germinability of herbaceous plant seeds change due to environmental conditions in West African savannas
}

\author{
Received: 2019-12-10; revised: 2019-12-14; accepted: 2019-12-18
}

\author{
Susanna E. Schmidt-Groh ${ }^{1 *}$, Markus Bernhardt-Römermann², Adjima Thiombiano ${ }^{3}$, Karen Hahn ${ }^{1}$ \\ ${ }^{1}$ Institute of Ecology, Evolution \& Diversity, J.W. Goethe University, Frankfurt a.M. / Germany \\ ${ }^{2}$ Institute of Ecology and Evolution, F. Schiller University, Jena / Germany \\ ${ }^{3}$ Department of Plant Biology and Physiology, University of Ouagadougou, Ouagadougou / Burkina Faso \\ *Corresponding author. E-Mail: susanna.schmidt-groh@live.de
}

\begin{abstract}
Summary: Knowledge about the herbaceous layer in relation to environmental factors in West African savannas is still scarce. Early life-cycle events like germination of the herbaceous species are of special interest, as these stages can play critical roles in establishing of the plants and determine population and community dynamics. We aim to assess intraspecific differences in the germinability of herbaceous savanna species with respect to environmental conditions to reveal adaptations in this early life cycle stage. The study was conducted in the Sudanian savanna of Burkina Faso in West Africa. We collected seeds of two annual herbs (Chamaecrista mimosoides, Spermacoce stachydea) along a climatic gradient from different habitats and land use types and conducted germination experiments under equal conditions in climate chambers. For both species several environmental factors showed a significant impact on the germination rates. While higher precipitation caused an increase in the germination rate only for S. stachydea, habitat conditions had a significant influence for both species. Intermediate habitats with balanced soil moisture caused an enhancement of the germination success. Moreover shrub cover had a positive effect on the germinability of $C$. mimosoides, whereas the germinability of $S$. stachydea decreased due to an increasing herbaceous cover. The study showed that certain environmental factors are able to modify the intraspecific variability of the germinability trait, which might affect the establishment of the species populations.
\end{abstract}

Keywords: savanna, West Africa, herbaceous layer, Climatic gradient, annual species, germinability, intraspecific trait variability.

\section{ADAPTATION INTRASPÉCIFIQUE À L'HABITAT: COMMENT LA CAPACITÉ DE GERMINATION DES GRAINES DES PLANTES HERBACÉES CHANGE-T-ELLE EN FUNCTION DES CONDITIONS ENVIRONNEMENTALES DANS LES SA- VANES OUEST AFRICAINES}

Résumé: Les connaissances sur la strate herbacée en relation avec les facteurs environnementaux dans les savanes Ouest africaines sont encore rares. Les événements précoces du cycle biologique, comme la germination des espèces herbacées, présentent un intérêt particulier, car ces stades peuvent jouer un rôle crucial dans l'établissement des plantes et être déterminant dans la dynamique des populations et des communautés. Notre objectif est d'évaluer les différences intraspécifiques dans la capacité de germination des espèces herbacées de savane selon les conditions environnementales afin de révéler les adaptations à ce stade précoce du cycle biologique. L'étude a été menée dans la savane soudanienne du Burkina Faso en Afrique de l'Ouest. Nous avons collecté des graines de deux espèces herbacées annuelles (Chamaecrista mimosoides, Spermacoce stachydea) le long d'un gradient climatique en fonction de différents types d'habitats et d'utilisation du terres. Nous avons ensuite mené des expériences de germination dans des conditions identiques à celles des savanes en utilisant des chambres climatiques. Pour les deux espèces, plusieurs facteurs environnementaux ont eu un impact significatif sur les taux de germination. Alors que les fortes précipitations n'ont provoqué une augmentation du taux de germination que pour S. stachydea, les conditions d'habitat quant à eux, ont eu une influence significative sur les deux espèces. Les habitats intermédiaires avec une humidité du sol équilibrée ont permis d'améliorer le succès de la germination. De plus, le taux de recouvrement des arbustes a eu un effet positif sur la germination de C. mimosoides, tandis que la capacité de germination de S. stachydea diminue avec l'augmentation du taux de recouvrement des herbacées. L'étude a montré que certains facteurs environnementaux sont capables de modifier la variabilité intraspécifique du trait de germination, ce qui pourrait affecter l'établissement de la population des espèces.

Mots-clés: savane, Afrique de l'Ouest, strate herbacée, gradient climatique, espèces annuelles, capacité de germination, variabilité intraspécifiques des traits.

\section{Intraspezifische Habitatanpassung: Wie sich die KeImfähigkeit Von Samen kRAutiger PfLANZen DURCH UMWELTBEDINGUNGEN IN DER WESTAFRIKANISCHEN SAVANNE VERÄNDERT}

Zusammenfassung: Der Wissensstand zur Krautschicht westafrikanischer Savannen im Zusammenhang mit verschiedenen Umweltfaktoren ist relativ lückenhaft. Von besonderem Interesse sind frühe Lebenszyklusereignisse, wie die Keimung der 
krautigen Arten, da diese Phasen eine entscheidende Rolle bei der Etablierung der Pflanzen spielen und die Dynamik von Population und Gemeinschaft bestimmen können. Ziel unserer Studie ist es intraspezifische Unterschiede in der Keimfähigkeit von krautigen Savannenarten in Bezug auf die Umweltbedingungen zu untersuchen, um ökologische Anpassungen in diesem frühen Lebenszyklusstadium zu erkennen. Die Studie wurde in der Sudanzone von Burkina Faso in Westafrika durchgeführt. Wir sammelten Samen von zwei einjährigen krautigen Arten (Chamaecrista mimosoides, Spermacoce stachydea) entlang eines Klimagradienten in verschiedenen Habitaten und Landnutzungstypen und führten damit Keimungsversuche unter gleichen Bedingungen in Klimakammern durch. Für beide Arten zeigten sich signifikante Einflüsse mehrerer Umweltfaktoren auf die Keimungsraten. Während höhere Niederschläge nur bei S. stachydea zu einer Erhöhung der Keimungsrate führte, hatten die Habitatbedingungen einen signifikanten Einfluss auf den Keimungserfolg bei beiden Arten. Intermediäre Habitat mit einer ausgewogenen Bodenfeuchte führten zu einem höheren Keimungserfolg. Darüber hinaus wirkte sich eine höhere Strauchbedeckung positiv auf die Keimungsfähigkeit von $C$. mimosoides aus, während die Keimungsfähigkeit von $S$. stachydea durch eine zunehmende krautige Bedeckung abnahm. Die Studie zeigte, dass bestimmte Umweltfaktoren in der Lage sind, die intraspezifische Merkmalsvariabilität der Keimungsfähigkeit von Arten zu verändern, was die Etablierung in Populationen beeinflussen kann.

Schlagworte: Savanne, Westafrika, krautige Schicht, Klimagradient, annuelle Arten, Keimfähigkeit, intraspezifische Merkmalsvariabilität

\section{INTRODUCTION}

Tropical savannas cover one eighth of the global land surface and half the area of Africa (SCHOLES \& ARCHER 1997, SCHOLES \& HaLl 1996). In this widespread ecosystem threefourths of the biomass is composed of herbaceous plants. Despite this fact, the ecological knowledge about herbaceous savanna species in relation to environmental conditions is still scarce. Particularly studies on early life-cycle events are of interest, as these stages can play critical roles in determining population and community dynamics of plants (DoNOHUE \& al.\& al. 2010, HuAng \& al. 2016). For example, the ecology of seeds and their germination patterns are important factors in the early life cycle, that decide on the establishment of the plant (ELBERSE \& BREMAN 1989, BASKIN \& BASKIN 1998) and can determine adaptation to environmental variation, species diversity, and community responses to climate change (KIMBALL \& al. 2010). Understanding the adaptive consequences of such functional traits as seed germination will allow us to explain and predict ecological dynamics (HuANG \& al. 2016).

In general, plant functional trait approaches enable an improved understanding of the performance of individuals and how they phenotypically adapt to their habitats and react to environmental changes (MCINTYRE \& al. 1995, DíAz \& al. 2004). Thus, plant functional traits describe the adaptations of plant individuals to their habitats. Flexibility in the shaping of the traits allows the plant to adapt to the prevailing environmental conditions. This can lead to large intraspecific differences in development of traits. Recent studies focus on intraspecific trait variation (ITV), for example, in leaf or seed traits (e.g. number of seeds or seed weight). This demonstrates the growing awareness of the importance to study intraspecific trait variation (e.g. AlbERT \& al. 2010, BolNiCK \& al. 2011, Helsen \& al. 2017). However, the intraspecific variation of other traits, such as the germination of seeds, are hardly considered (FUNK \& al. 2017).

In this study we aim to assess intraspecific differences in the germinability of herbaceous savanna species with respect to environmental conditions to reveal adaptations in this early life cycle stage due to environmental parameters. We collected seeds of two typical West African herbaceous savanna species in different habitats, inside and outside protected areas, along a precipitation gradient in Burkina Faso to conduct germination experiments under standardized conditions. Such germination studies with climate chambers under controlled conditions (Jensch \& Poschlod 2008, Kos \& Poschlod 2007, 2010, Sy \& al. 2001, WePPler \& STÖCKLIN 2006) allow investigating whether germination rates show differences that can be related to the environmental conditions to which the populations were exposed. By this, environmental factors, which play an important role in determining the germinability of the plants, can be identified. This will allow insights into the resilience of plant species to environmental changes, such as climate change.

\section{Material and Methods}

\subsection{Study species and study area}

We collected seeds of two herbaceous species Chamaecrista mimosoides (Fabaceae), and Spermacoce stachydea (Rubiaceae) (Fig. 1). They are typical representatives of life forms and life-history types of the savanna herbaceous cover, namely annual herbs, and are widespread over the entire climatic range of the study region. Thus, this gives them particular value as model organisms for this study. An essential difference of the two species is due to the palatability (Devineau \& Fournier 2005). C. mimosoides is considered as highly palatable by cattle, whereas the palatability of S. stachydea is low.

The seeds for the germination study were collected in Burkina Faso, a West African country located between sub-arid and sub-humid zones with a clear precipitation gradient from the drier North to the more humid South. The year is divided in a longer dry season and a shorter rainy season, from about June to October (Thiombiano \& KampManN 2010). We considered four study areas situated along a precipitation gradient from the North to the South Sudanian zone in Burkina Faso (see Fig. 2 and Table 1). In each study area we selected plots in a protected area in which anthropogenic influences are prohibited or reduced to a minimum, and in surrounding land use areas. Furthermore, plots have been established on three different habitat types in the protected area and in the land use area. The habitats were differentiated according to soil moisture into dry, intermediate and wet habitats. Each plot had a size of $10 \times 10$ meters with a minimum distance of $500 \mathrm{~m}$ to each other. We collected all seeds of 6 individuals from each species per plot, if present. The seeds were stored in silica gel at room temperature, transported to Germany and stored over the next few weeks 

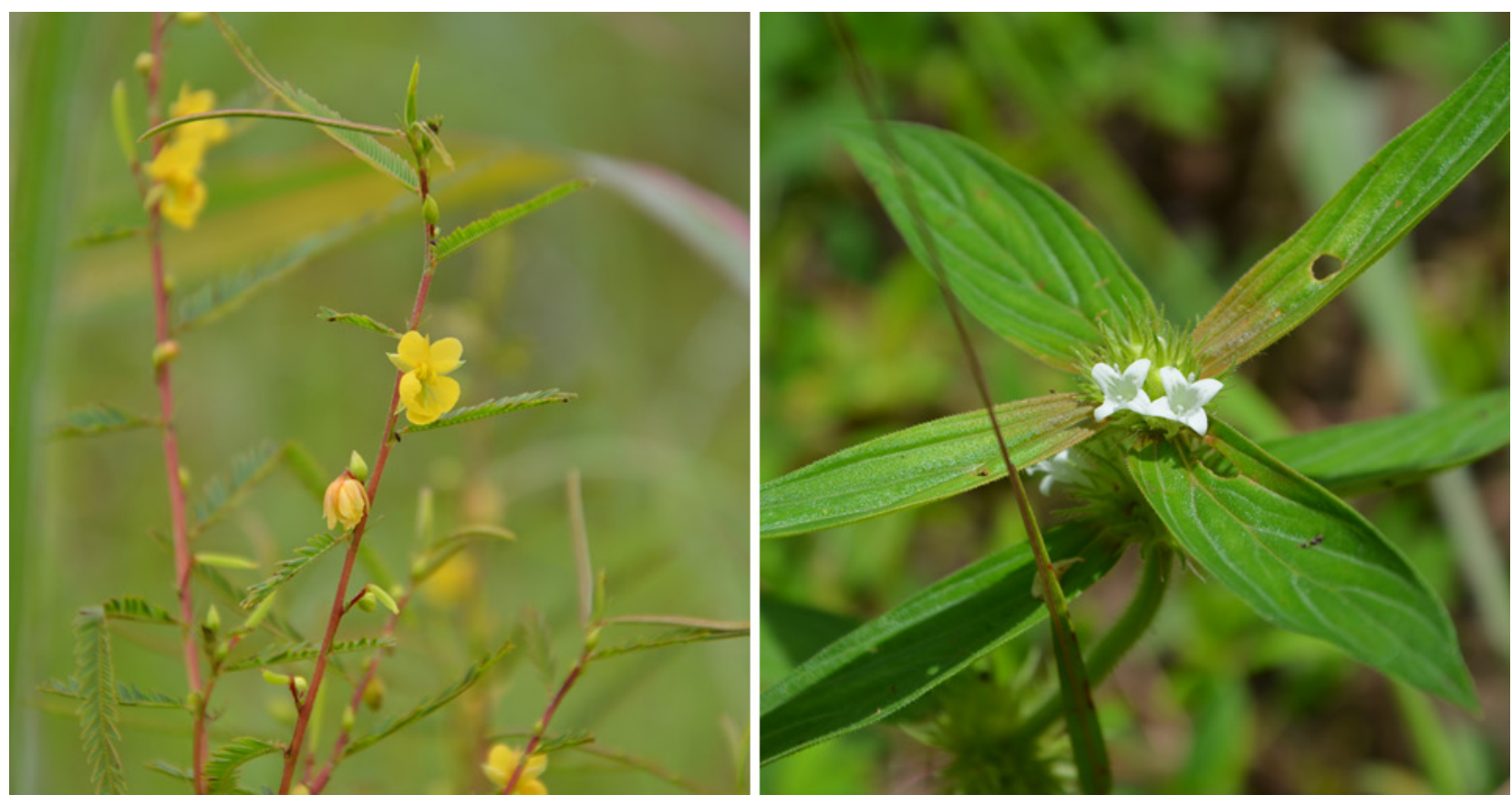

Fig. 1: Flowering individual of C. mimosoides (left) and S. stachydea (right) / Individu en fleur de C. mimosoides (à gauche) et S. stachydea (à droite)

at room temperature until the germination experiments in the laboratory started.

In addition to the above mentioned factors of climate (represented by the annual precipitation rate of the study areas), land use (protected zone and fallow) and habitat (dry, intermediate and wet), further environmental factors were measured and included in the analysis: 1 . The vegetation structure at the selected plots: amount of bare soil, tree cover, shrub cover, herb cover (in \%) and average tree height, shrub height and herb height (in $\mathrm{m}$ ); 2. Soil samples were

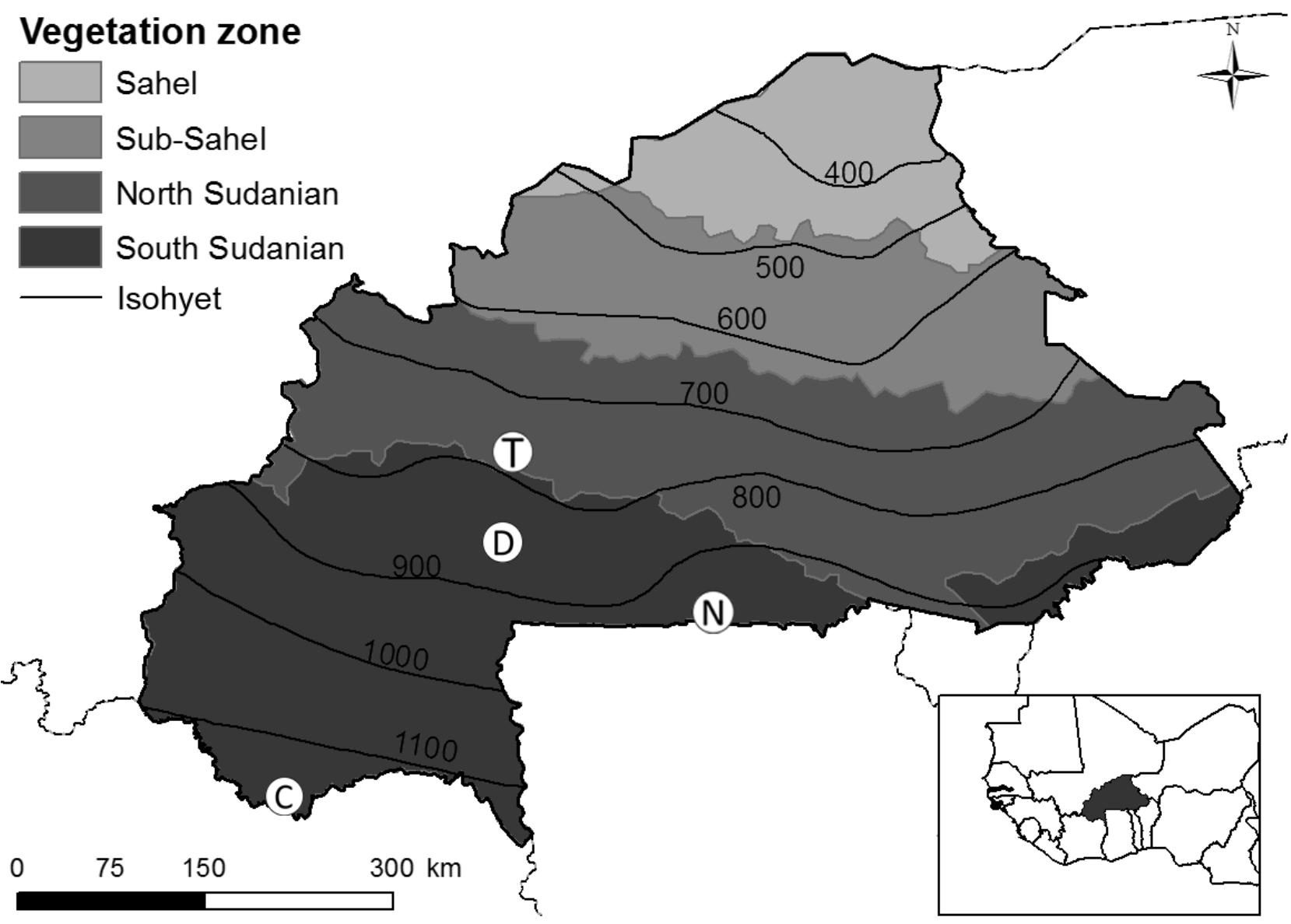

Fig. 2: Study sites in Burkina Faso differing in precipitation rate, indicated by letters refer to Table 1/ Les sites d'étude au Burkina Faso diffèrent par leur précipitations, indiquées par des lettres se référant au Table 1. 
Table 1: Characterization of study sites by annual precipitation / Caractérisation des sites d'étude par précipitations annuelles (Precip.).

\begin{tabular}{|l|l|l|l|}
\hline Study site & Vegetation zone & Precip.[mm] & Year of survey \\
\hline (T) Tiogo & North Sudanian & 758 & 2012 \\
\hline (D) Deux Balés & South Sudanian & 888 & 2013 \\
\hline (N) Nazinga & South Sudanian & 943 & 2012 \\
\hline (C) Comoé-Léraba & South Sudanian & 1125 & 2013 \\
\hline
\end{tabular}

used to determine the composition of the soils. For this purpose, five soil samples were taken from each plot to a depth of $20 \mathrm{~cm}$, and merged into one composite sample for soil analysis (for details see: JAKUBKA \& al. 2017). Data of the following soil factors were included in this study: the amount of stone, silt and sand, $\mathrm{pH}$ value, carbon-to-nitrogen ratio ( $\mathrm{C} / \mathrm{N}$ ratio), phosphorus content and Cation-exchange capacity (CEC).

\subsection{Germination experiments}

In a first step we tested for both species with small samples (about 10 seeds per dish and 10 dishes per species) different temperature regimes and pretreatments to break the seed dormancy (e.g. scarification of seeds) to identify optimal germination conditions. The seeds of both species germinated best in the climate chambers at a temperature regime of $30^{\circ} \mathrm{C}$ and $25^{\circ} \mathrm{C}$ for 12 hours alternately, according to a 12 hours' diurnal light regime. The germination of C. mimosoides is highly enhanced by scarification, since the hard seed coat hinders the absorption of water (CISsÉ 1986). Based on our tests, we treated the seeds with scarification by grinding the seed coats. Seeds of $S$. stachydea germinate reliable after light scarification by grinding of the coat and soaking in water for one week (Elberse \& Breman 1989). This was confirmed in our pre-tests. For the full germination experiment for each species 30 seeds per plot were pretreated in this way and placed in Petri dishes. For some plots seed numbers were lower, but a minimum of 5 seeds was available in all cases. C. mimosoides seeds were deposited on a filter paper soaked with deionized water. The seeds of $S$. stachydea were allowed to float in a small amount of deionized water. All Petri dishes were closed by Parafilm to reduce the evaporation of water from the dishes. The occurrence of the radicle was considered as germination success, for which the seeds were given a maximum of eight weeks (SсOTT \& al. 2010). Usually the germination occurred within the first two weeks. All germinated seeds were recorded.

\subsection{Data analysis}

The total number of germinated seeds and ungerminated seeds was taken to calculate the germination rate. We used a general linear model (glm) with binomial distributed error structure to investigate the influence of the recorded environmental factors (explanatory variable) on germinability. All continuous environmental variables were standardized to zero mean, unit variance. The models were simplified via backward selection. The statistical analyses were performed in R.3.4.2 (R CORE TEAM 2017).

\section{RESULTS}

The germination rates of the two species showed considerable differences. C. mimosoides seeds germinated with an average rate of over $80 \%$, while the average germination rate for $S$. stachydea was about $45 \%$. Both species showed a similar range of variation $( \pm 20 \%)$ in their germination rates.

In regard to the impact of environmental factors several parameters had significant effects on the germination rate of both species. Table 2 shows the results of the glm. Precipitation had a significant effect only on the germination rates of $S$. stachydea, while the germinability of the seeds of C. mimosoides remained unaffected by this factor. The germination rate of $S$. stachydea increased with higher precipitation (Fig. 3). In regions with less precipitation, the germinability of this species was reduced. However, the factor habitat showed a significant influence on both species. Seeds collected from individuals of C. mimosoides (Fig. 4) and S. stachydea (Fig. 5) on intermediate habitats, had significantly higher germination rates compared to seeds collected on dry and wet habitats. Hence intermediate habitats had a positive effect on the germinability of the seeds. In regard to vegetation structure, the germinability of the seeds of C. mimosoides was influenced significantly by shrub cover. An increasing shrub cover had a positive effect on the germination rate (Fig. 6). Contrary, the germinability of the S. stachydea seeds was influenced by the herbaceous cover. The germination rates decreased significantly with increasing herb cover on the plots (Fig. 7). Thus, a denser herb layer had a negative effect on the germinability of $S$. stachydea seeds.

All other environmental factors (land use, soil parameters, tree cover, height of vegetation layers) had no effect on the germination rates.

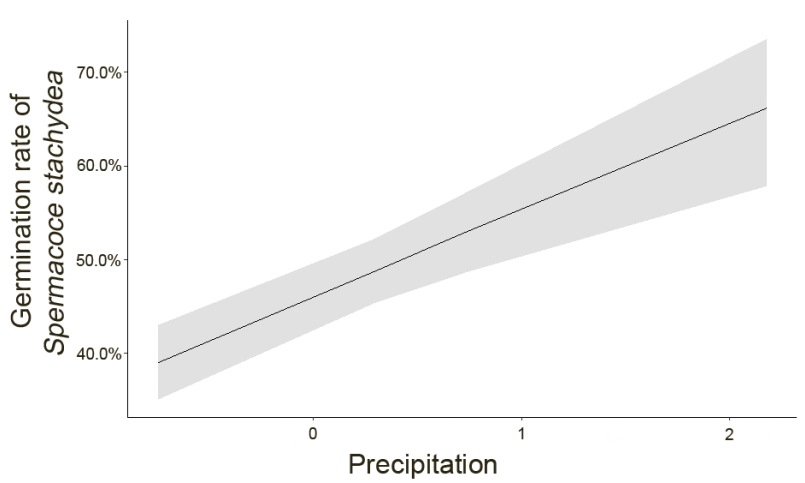

Fig. 3: Model output of GLM 2, Germination rate of S. stachydea depending on precipitation, environmental data were standardized / Débit de GLM 2, taux de germination de S. stachydea selon les précipitations, les valeurs environnementales sont standardisées. 


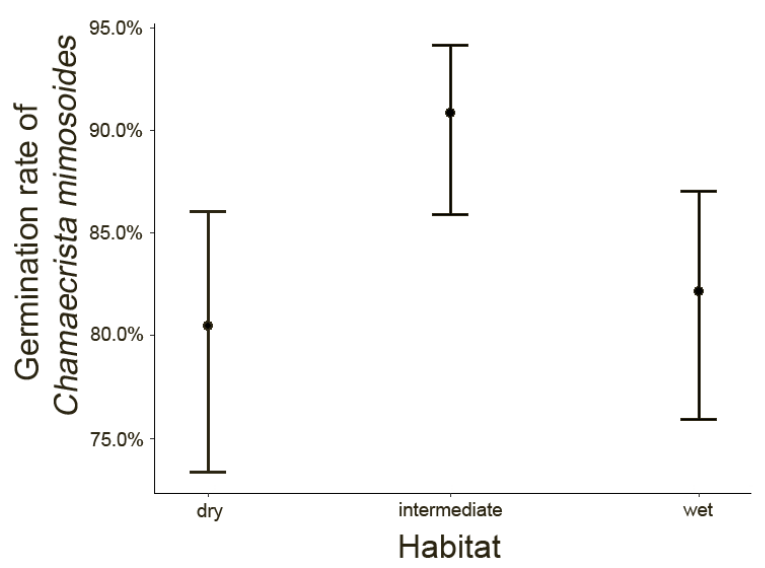

Fig. 4: Model output of GLM 1, Germination rate of C. mimosoides depending on habitat / Débit de GLM 1, taux de germination de C. mimosoides selon l'habitat.



Fig. 6: Model output of GLM 1, Germination rate of C. mimosoides depending on shrub cover, environmental data were standardized / Débit de GLM 1, taux de germination de C. mimosoides selon la couverture arbustive, les valeurs environnementales sont standardisées.

\section{Discussion}

In regard to the intraspecific trait variability of seed germination, the environmental factor of 'habitat' showed the most prominent effect. The seeds from individuals of both species with a provenance from intermediate habitats showed an enhanced germination success. We assume that the more balanced soil moisture on the intermediate habitats

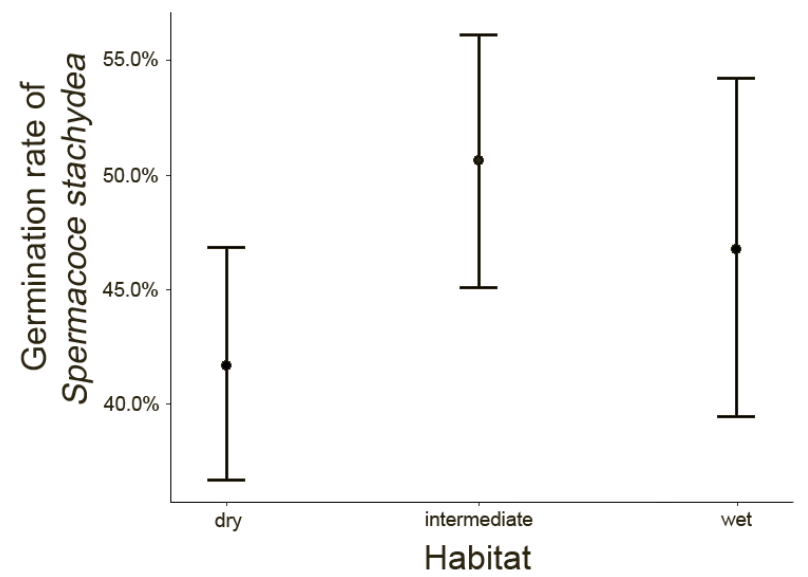

Fig. 5: Model output of GLM 2, Germination rate of S. stachydea depending on habitat / Débit de GLM 2, taux de germination de S. stachydea selon l'habitat.

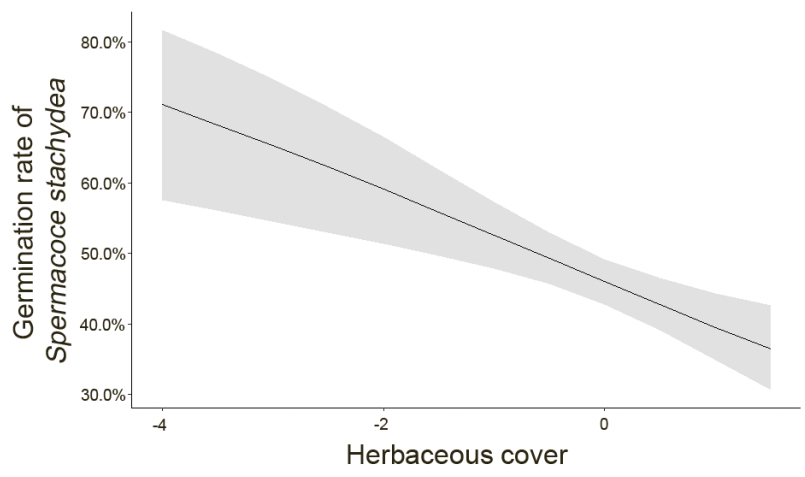

Fig. 7: Model output of GLM 2, Germination rate of S. stachydea depending on herbaceous cover, environmental data were standardized / Débit de GLM 2, taux de germination de $S$. stachydea selon la couverture herbacée, les valeurs environnementales sont standardisées.

is favorable for both species and thus lead to better performance with higher germination rates. This is in concordance with Le Bourgeois \& Merlier (1995), who describe that both species can be found on soils that are well ventilated. In case of strong waterlogging these species might have problems to establish well. In regard to drier habitats no information was found.

Table 2: Results of the general linear models. / Résultats des modèles linéaires généraux.

\begin{tabular}{|c|c|c|c|c|c|}
\hline $\begin{array}{l}\text { GLM } 1 \\
\text { Chamaecrista mimosoides }\end{array}$ & Estimate & SE & t value & $\operatorname{Pr}$ & \\
\hline (Intercept) & 1,4155 & 0,2033 & $-6,962$ & $1,87 \mathrm{E}-10$ & $* * *$ \\
\hline Intermediate Habitat & 0,8777 & 0,3191 & $-2,751$ & 0,0069 & $* *$ \\
\hline Wet Habitat & 0,1103 & 0,2807 & $-0,393$ & 0,6949 & \\
\hline Shrub Cover & 0,3689 & 0,1362 & $-2,709$ & 0,0077 & $* *$ \\
\hline $\begin{array}{l}\text { GLM } 2 \\
\text { Spermacoce stachydea }\end{array}$ & Estimate & SE & $t$ value & Pr & \\
\hline (Intercept) & $-0,3371$ & 0,1064 & 3,168 & 0,0017 & $* *$ \\
\hline Precipitation & 0,3829 & 0,0755 & $-5,068$ & 7,91E-07 & $* * *$ \\
\hline Intermediate Habitat & 0,3603 & 0,1595 & $-2,259$ & 0,0248 & $*$ \\
\hline Wet Habitat & 0,2061 & 0,1889 & $-1,091$ & 0,2762 & \\
\hline Herbaceous Cover & $-0,2648$ & 0,0744 & 3,561 & 0,0004 & $* * *$ \\
\hline
\end{tabular}


Moreover, the germinability of S. stachydea reacted positively to the increase in precipitation which indicates that the optimum for this species is most probably in areas with higher precipitation rates in the South-Sudanian zone. According to Le Bourgeois \& MerLIER (1995) the species has a wide distribution in the drier Sahelo-Sudanian region, but can also occur further south in areas with higher precipitation. Our findings on the germination rates point to more favorable growing conditions in the more humid areas.

Vegetation structure showed also significant impact on the germinability of both species. The germination success of C. mimosoides seeds was positively influenced by a provenance from plots with a higher shrub cover. This might be due to the fact, that the performance of herbaceous plants can be improved by increased nutrient uptake from the uppermost soil layer due to shrub litter enriched soils (Mordelet And Menaut 1995). Other studies point to the improvement of conditions for herbaceous plants through isolated shrubs or a moderate increase in shrub cover, for example through reduced water stress (GEISSLER \& al. 2019, SOLIVERES AND ELDRIDGE 2014). Moreover, increased shading due to higher shrub cover can have negative effects on savanna grasses (DoHN \& al. 2013) and thus, diminish the competition for less shade sensitive herbaceous species.

The seeds of $S$. stachydea germinated more frequently when the plots, on which the original plants grew, had a sparser herbaceous layer. We assume that a less dense herbaceous cover has advantages for the performance of $S$. stachydea as it might lead to less competition among herbaceous species, belowground in the soil for nutrients and water as well as above ground for light availability. This might result in a better performance with higher photosynthesis activity and thus increased metabolic accumulation.

Overall, our results indicate that the germination success is only related to very few of the investigated environmental conditions to which the plant individuals of our two studied species were exposed. An unanticipated finding was that the measured soil parameters had no effect on the germination success of the seeds. This is in contrast to our expectations, as other studies have found, that especially the nutrient availability of the soil can have an impact on plant performance (for example Wright \& al. 2004), which should also be reflected in the performance of the germinability.

\section{CONCLUSION}

To the best of our knowledge, this is the first study to investigate intraspecific variation of germination success of seeds from sites with different environmental parameters. It showed that the intraspecific variation of the germinability related to environmental influences is quite low, when compared to other investigated traits, such as leaf traits (e.g. SLA), which are more affected by site conditions (HELSEN $\&$ al. 2017). However, habitat conditions and vegetation structure, as well as the precipitation rate for S. stachy$d e a$, affected significantly the germinability of our species. Changes in these environmental factors therefore may lead to changes in this first life cycle stage of the species populations.

\section{Acknowledgments}

We acknowledge the funding by the DFG project (BE 4143/2-1, HA 6789/1-1) "Responses of Herbaceous Savanna Vegetation to Land Use and Habitat Conditions: Investigations along a Climatic Gradient in West Africa". Furthermore we thank the Ministry of Scientific Research and Innovation of Burkina Faso for research permit and all field assistants for their tireless efforts. And we thank Dr. Issouf Zerbo for helping with the translation into French.

\section{REFERENCES}

Albert CH, Thuiller W, Yoccoz NG, Soudant A, BouCHER F, SACCone P \& LaVorel S (2010): Intraspecific Functional Variability: Extent, Structure and Sources of Variation. Journal of Ecology 98: 604-13. https://doi.org/10.1111/ j.1365-2745.2010.01651.x.

BASKIN CC \& BASKIN JM (1998): Seeds: Ecology, biogeography, and evolution of dormancy and germination (1st ed.). San Diego: Academic Press.

Bolnick DI, Amarasekare P, AraúJo MS, Bürger R, Levine JM, Novak M, Rudolf VHW, Schreiber SJ, Urban MC \& VASSEUR D (2011): Why intraspecific trait variation matters in community ecology. Trends Ecol Evol 26: 183192. doi: 10.1016/j.tree.2011.01.009.

Cissé AM (1986): Dynamique de La Strate Herbacée Des Pâturages de La Zone Sud-Sahélienne. Landbouwuniversiteit Wageningen. http://library.wur.nl/WebQuery/ clc/242102.

Devineau JL \& Fournier A (2005): To What Extent Can Simple Plant Biological Traits Account for the Response of the Herbaceous Layer to Environmental Changes in FallowSavanna Vegetation (West Burkina Faso, West Africa)? Flora - Morphology, Distribution, Functional Ecology of Plants 200: 361-75. https://doi.org/10.1016/j.flora.2005.01.005.

Díaz S, Hodgson JG, Thompson K, Cabido M, Cornelissen JHC, Jalili A, Montserrat-Martí G, Grime Grime JP, ZARRINKAMAR F, ASRI Y, BAND SR, BASCONCELO S, Castro-Díez P, Funes G, Hamzehee B, Khoshnevi M, Pérez-Harguindeguy N, Pérez-Rontomé MC, Shirvany FA, Vendramini F, Yazdani S, Abbas-Azimi R, Bogaard A, Boustani S, Charles M, Dehghan M, De Torres-Espuny L, Falczuk V, Guerrero-Campo J, Hynd A, Jones G, Kowsary E, Kazemi-Saeed F, Maestro-Martínez M, Romo-Díez A, Shaw S, Siavash B, Villar-Salvador P \& ZaK MR (2004): The Plant Traits That Drive Ecosystems: Evidence from Three Continents. Journal of Vegetation Science 15: 295-304. https://doi.org/10.1111/j.1654-1103.2004. tb02266.x.

Dohn J, Dembélé F, Karembé M, Moustakas A, Amévor KA \& HANAN NP (2013): Tree effects on grass growth in savannas: competition, facilitation and the stress-gradient hypothesis. Journal of Ecology 101: 202-209. https://doi. org/10.1111/1365-2745.12010.

Donohue K, De Casas RR, Burghardt L, Kovach K \& WiLLIS CG (2010): Germination, postgermination adaptation, and species ecological ranges. Annual Review of Ecology, Evolution, and Systematics 41: 293 - 319. https://doi. org/10.1146/annurev-ecolsys-102209-144715.

Elberse WT \& Breman H (1989): Germination and Establishment of Sahelian Rangeland Species. Oecologia 80: 477-84. http://www.springerlink.com/index/ R11T32TJ40375102.pdf.

Funk JL, Larson Je, Ames GM, Butterfield BJ, Cavender-Bares J, Firn J, Laughlin DC, Sutton-Grier AE, Williams L \& Wright J (2017): Revisiting the Holy 
Grail: Using Plant Functional Traits to Understand Ecological Processes. Biological Reviews 92: 1156-73. https://doi. org/10.1111/brv.12275.

Geissler K, Hahn C, Joubert D \& Blaum N (2019): Functional Responses of the Herbaceous Plant Community Explain Ecohydrological Impacts of Savanna Shrub Encroachment. Perspectives in Plant Ecology, Evolution and Systematics 39: 125458. https://doi.org/10.1016/j. ppees.2019.125458.

Helsen K, Acharya KP, Brunet J, Cousins SaO, Decoce G, Hermy M, Kolb A, Lemke IH, Lenoir J, Plue J, Verheyen K, De Frenne P \& Graae BJ (2017): Biotic and Abiotic Drivers of Intraspecific Trait Variation within Plant Populations of Three Herbaceous Plant Species along a Latitudinal Gradient. BMC Ecology 17: 1-12. https://doi. org/10.1186/s12898-017-0151-y.

Huang Z, Liu S, Bradford KJ, Huxman TE \& Venable DL (2016): The contribution of germination functional traits to population dynamics of a desert plant community. Ecology, 97: 250-261. https://doi.org/10.1890/15-0744.1.

JakubKa D, Lessmeister A, Hahn K, Traoré S, SchuMANN K, Thiombiano A \& Bernhardt-RömermanN M (2017): Effects of Climate, Habitat and Land Use on the Cover and Diversity of the Savanna Herbaceous Layer in Burkina Faso, West Africa. Folia Geobotanica 52: 129-42. https://doi.org/10.1007/s12224-017-9289-9.

Jensch D \& Poschlod P (2008): Germination Ecology of Two Closely Related Taxa in the Genus Oenanthe: Fine Tuning for the Habitat? Aquatic Botany 89: 345-51. https:// doi.org/10.1016/j.aquabot.2008.03.013.

Kimball S, Angert AL, Huxman TE \& Venable DL (2010): Contemporary climate change in the Sonoran Desert favors cold-adapted species. Global Change Biology 16: 1555 -1565. https://doi.org/10.1111/j.13652486.2009.02106.x

Kos M \& Poschlod P (2007): Seeds Use Temperature Cues to Ensure Germination under Nurse-Plant Shade in Xeric Kalahari Savannah. Annals of Botany 99: 667-75. https:// doi.org/10.1093/aob/mcl293.

Kos M \& Poschlod P (2010): Why Wait? Trait and Habitat Correlates of Variation in Germination Speed among Kalahari Annuals. Oecologia 162: 549-59. https://doi. org/10.1007/s00442-009-1472-0.

Le Bourgeois T \& Merlier H (1995): Adventrop - Les adventices d'Afrique soudano-sahelienne. CIRAD-CA, Montpellier.

Menges ES (1991): Seed Germination Percentage Increases with Population Size in a Fragmented Prairie Species. Conservation Biology 5: 158-164. https://doi. org/10.1111/j.1523-1739.1991.tb00120.x.
Mcintyre S, Lavorel S \& Tremont RM (1995): Plant life-history attributes - their relationship to disturbance responses in herbaceous vegetation. Journal of Ecology 83: 31-44. doi:10.2307/2261148. www.jstor.org/stable/2261148.

Mordelet P \& Menaut JC (1995): Influence of Trees on Above-Ground Production Dynamics of Grasses in a Humid Savanna. Journal of Vegetation Science 6: 223-28. https:// doi.org/10.2307/3236217.

R Core Team (2017): R: A language and environment for statistical computing. R Foundation for Statistical Computing, Vienna, Austria. https://www.R-project.org/.

Scholes RJ \& Hall DO (1996): The carbon budget of tropical savannas, woodlands, and grasslands. In Modelling Terrestrial Ecosystems, ed. A Breymeyer, D Hall, J Melillo, G Agren: 69-100. Chichester: Wiley.

SCHOLES RJ \& ARCHER SR (1997): Tree-Grass Interactions in Savannas. Annual Review of Ecology and Systematics 28: 517-44. http://www.jstor.org/stable/10.2307/2952503.

Scott KA, Setterfield SA, Douglas MM \& ANDERSen AN (2010): Environmental Factors Influencing the Establishment, Height and Fecundity of the Annual Grass Sorghum Intrans in an Australian Tropical Savanna. Journal of Tropical Ecology 26: 313-22. https://doi.org/10.1017/ S0266467409990629.

Soliveres S \& EldRIDGe DJ (2014): Do Changes in Grazing Pressure and the Degree of Shrub Encroachment Alter the Effects of Individual Shrubs on Understorey Plant Communities and Soil Function? Functional Ecology 28: 530 537. https://doi.org/10.1111/1365-2435.12196.

Sy A, Grouzis M \& Danthu P (2001): Seed Germination of Seven Sahelian Legume Species. Journal of Arid Environments 49: 875-82. https://doi.org/10.1006/jare.2001.0818.

Thiombiano A \& Kampmann D (eds) (2010): Biodiversity Atlas of West Africa, Volume II: Burkina Faso. Ouagadougou \& Frankfurt/Main. https://www.uni-frankfurt. de/47671312/

Weppler T \& Stöcklin J (2006): Does Pre-Dispersal Seed Predation Limit Reproduction and Population Growth in the Alpine Clonal Plant Geum reptans? Plant Ecology 187: 277-87. https://doi.org/10.1007/s11258-006-9141-4.

Wright I, Reich P, Westoby M, Ackerly DD, Baruch Z, Bongers F, Cavender-Bares J, Chapin T, Cornelissen JHC, Diemer M, Flexas J, Garnier E, Groom PK, Gulias J, Hikosaka K, Lamont BB, Lee T, Lee W, Lusk C, Midgley JJ, Navas ML, Ninemets Ü, Oleksyn J, Osada N, Poorter H, Poot P, Prior L, Pyankov VI, Roumet C, Thomas SC, Tuoelker MG, Veneklaas EJ \& Villar R (2004): The worldwide leaf economics spectrum. Nature 428: 821-827. doi:10.1038/nature02403. 